\title{
Assessment of Ornamental Value of Vinca Major 'Variegata' and Arabis Caucasica 'Deep Rose' Species in Different Systems of Culture
}

\author{
Roxana NEGREA ${ }^{1 *}$, Lucia DRAGHIA ${ }^{1}$, Gheorghii CIOBOTARI ${ }^{1}$ \\ ${ }^{1}$ Faculty of Horticulture, University of Agricultural Sciences and Veterinary Medicine „Ion Ionescu \\ de la Brad", 3, M. Sadoveanu Alley, 700490, Iasi, Romania \\ *)corresponding author, e-mail: roxana.acfrance@gmail.com
}

BulletinUASVM Horticulture 72(2) / 2015

Print ISSN 1843-5254, Electronic ISSN 1843-5394

DOI:10.15835/buasvmcn-hort:10988

\begin{abstract}
Vinca major L. is a Mediterranean species, hemicryptophyte, cultivated in Romania as ornamental plan on walls or cliff arrangements. Due to its biologic characteristics it can be easily cultivated on roofs and harmoniously associated with species Arabis caucasica L. for the setup of green roofs. A species native to the mountain areas of Asia and Northern Africa, Arabis caucasica L. (syn. A.albida Stev.) has been introduced and naturalized in almost all of Europe, including Romania, and at the present time it is part of the ornamental assortment of alpine gardens insuring, through their color and flowering abundance the specific décor in the summer period. The paper has the purpose of analyzing the influence of some culture systems on the ornamental potential of Vinca major plants 'Variegata' L. și Arabis caucasica 'Deep Rose' L. For this purpose we have analyzed the influence of the culture location and the used substrate on the plan growing and development abilities. Experiences were based on the installation of roof and field culture, as well as on the use of three culture substrates of different compositions: $\mathrm{a}_{1}$ - forest soil; $\mathrm{a}_{2}$-Novobalt peat mixture (43\%), coconut fiber (30\%), composted bark (23\%), alginate (4\%); $\mathrm{a}_{3}-$ blonde peat (40\%), brown peat (30\%), sand (10\%) and forest soil (20\%). Planting the Vinca major 'Variegata' and Arabis caucasica 'Deep Rose' plants in different culture systems and different types of substrates has determined a differential behavior, with better results, for both species, in case of the substrate comprised of: Novobalt (43\%), coconut (30\%), composted bark (23\%), alginate (4\%). Taking into consideration the specifics of the Vinca sort, it is highlighted that it had a remarkable evolution which convinced me to recommend it in landscape arrangements made on roofs and terraces.
\end{abstract}

Keywords: Arabis caucasica 'Deep Rose', green roofs, substrate, Vinca major 'Variegata'.

\section{INTRODUCTION}

Green roofs are a landscaping method that combines esthetics with the ecologic functions of these types of landscaping (Compagnone, 2009). The esthetics and most of all the functionality of such an area are primordial aspects (Toma, 2003), anchored in the determination of the selection of the most lendable culture systems (Higgins, 2005; Pyšek, 2002; Bruce, 2011). In order to reach our objective we have carried out a comparative analysis regarding the behavior of Vinca major 'Variegata' L. and Arabis caucasica 'Deep Rose' L. plants cultivated on three types of substrates in containers, located both on the roof and on the soil level (Zheng, 2013; Negrea, Draghia , Ciobotari, 2014).

A species native to the mountain areas of Asia and Northern Africa, Arabis caucasica L. (syn. A.albida Stev.) has been introduced and naturalized in almost all of Europe, including Romania (Sîrbu and Oprea, 2011; Săvulescu, 1976). At present, Arabis caucasica cultivars are part of the ornamental assortment of alpine gardens (Cantor, Pop, 2005), insuring, through their color and flowering abundance, the specific décor in the summer period (Cantor, 2009). Due 
to the rich flowering and special shape, it can be planted in groups in the setup of roofs, but it also lends itself to solitary setup, as isolated individuals in the alpine gardens and not only (Șelaru, 2007; Cristea, 2013).

Perennial, hemicryptophyte plant, about 15 $\mathrm{cm}$ in height and with a bush diameter of 60-80 cm (Draghia, Chelariu, 2011), Vinca major L. is a Mediterranean species, that is frequently seen in many other European regions such as Austria or Bulgaria (Borza, 1925). It is cultivated in our country as an ornamental plan on walls and cliff arrangements, especially in Sighisoara, ever since 1816 (Borza, 1925), later, in 1978 it was reported as wild plant in the forest of Muntenia region (Sîrbu and Oprea, 2011; Borza and Nyarady, 1931).

\section{MATERIALS AND METHODS}

The used biologic material comprised 108 mature plants of Vinca major 'Variegata' L. and 108 Arabis caucasica 'Deep Rose' L. plants, purchased in $12 \mathrm{~cm}$ pots from the nurseries. The experimental scheme for each culture location (roof and field) includes three variants each with three repetitions, in which we have used three types of culture substrate: $\mathrm{a}_{1}$ - forest soil; $\mathrm{a}_{2}$ - mixture of Novobalt peat $(43 \%)$, coconut fiber $(30 \%)$, composted bark (23\%), alginate (4\%); $\mathrm{a}_{3}$ - blonde peat $(40 \%)$, brown peat $(30 \%)$, sand $(10 \%)$ and forest soil (20\%). The experiment was mounted identically on the soil level and on the roof, thus resulting, in total a number of 6 variants: on the roof - variants $V_{1}$ (substrate $a_{1}$ ), $V_{2}$ (substrate $a_{2}$ )

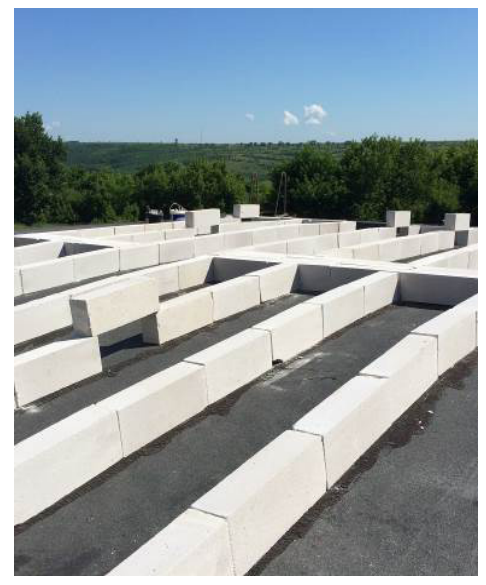

a)

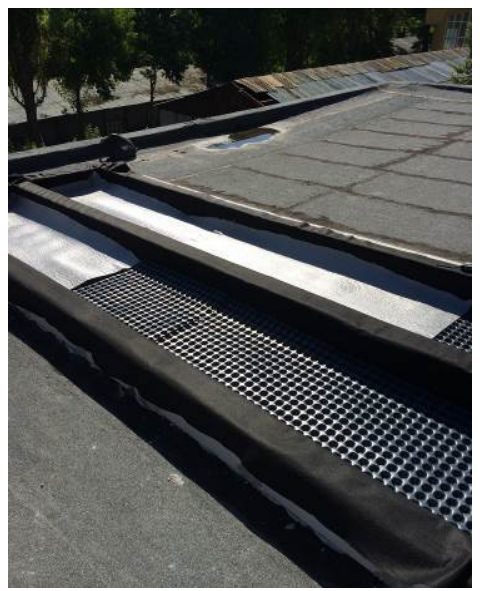

d)

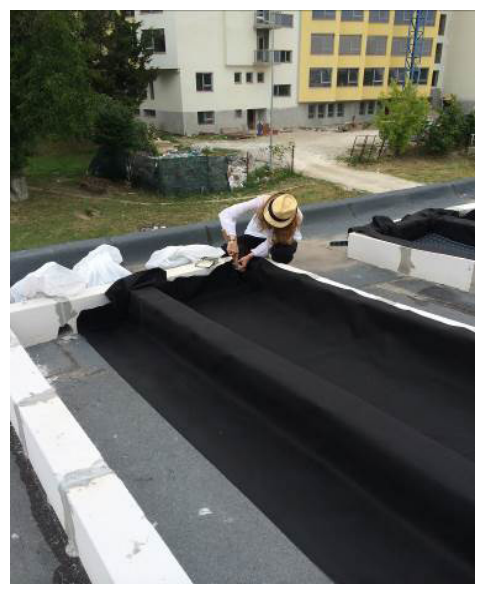

b)

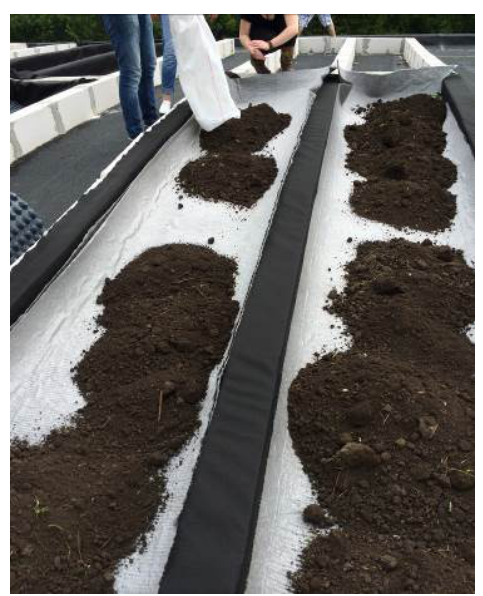

f)

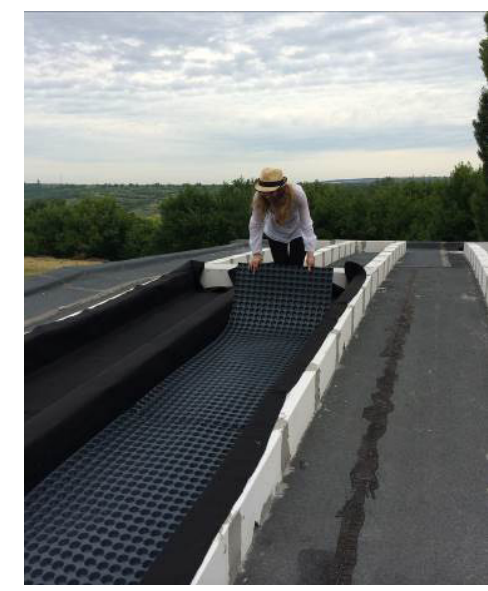

c)

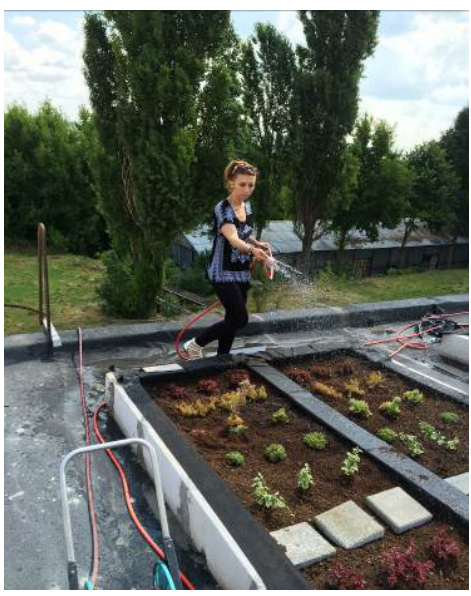

g)

Fig. 1 Setup of roof experiments: a) BCA brick systematization (9/05/2014); b) fixing the MacTex BN40.1 membrane (14/05/2014); c) setting the Maxistud membrane (24/05/2014); d) fixing the Q-Drain ZM 8 membrane(26/05/2014); e) setting the culture substrate(28/05/2014); f) planting the vegetal material

(31/05/2014). 
and $V_{3}$ (substrate $a_{3}$ ), and on the field - variants $V_{4}$ (substrate $\mathrm{a}_{1}$ ), $\mathrm{V}_{5}$ (substrate $\mathrm{a}_{2}$ ) and $\mathrm{V}_{6}$ (substrate $\mathrm{a}_{3}$ ).

The uniform vegetal material was planted in the spring of 2014 in experimental lots from the Floriculture Department and the roof of a building belonging to the University of Agricultural Sciences and Veterinary Medicine Iasi, in order to also carry out a comparative analysis between their development on the ground and on the roof. The experimental lots were built from 18 especially prepared containers of $480 \mathrm{~cm}$ length and $80 \mathrm{~cm}$ width.

For container mounting we have used innovative materials meant to protect both the insulation of the roof they were mounted on and the cultivated plants. For good container insulation, we used a special membrane, called MacTex BN40.1 200gr, and in order to retain rainwater in the containers we used Maxistud, which is a membrane with tronconic protuberations of HDPE, of high thickness $(20 \mathrm{~mm})$ and exceptional mechanic characteristics, that can retain up to
$6 l$ of water on $1 \mathrm{~m}^{2}$. Over this membrane, for the distribution of the substrate weight and in order to insure good water drainage, we used a Q-Drain ZM 8 membrane (Fig. 1).

During the research, we have made phenological observations depending on planting date, shoot occurrence date and determination on plant growth and development. During the experiments, we have analyzed the morphologic characteristics of the plants from the two species: number of flowers and leaves, length and width of bushes and number of shoots.

Experimental results regarding the behaviour of the species taken into study were processed using variation analysis (Cepoiu, 1964), correlation factor calculation (Săulescu, 1967), and the significant differentiation between the experimental variants was made in comparison with their average.

\section{RESULTS AND DISCUSSION}

Following the determinations carried out for Vinca major 'Variegata' and Arabis caucasica 'Deep

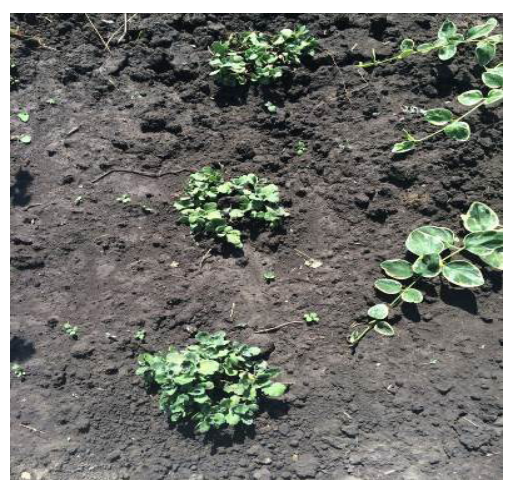

a)

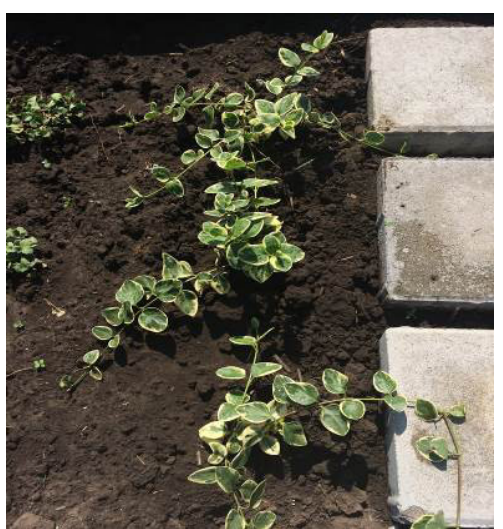

d)

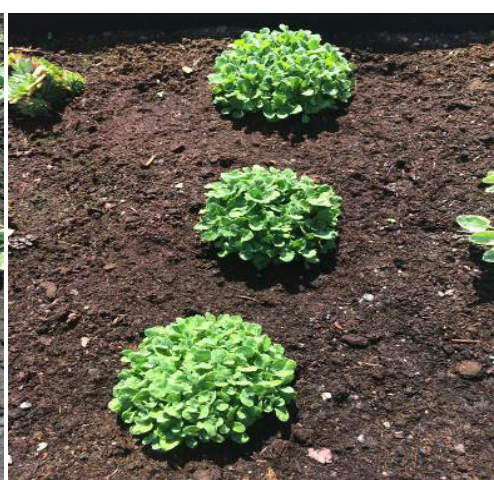

b)

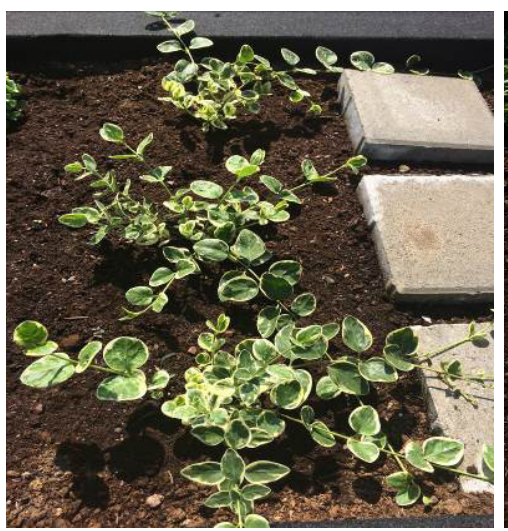

f)

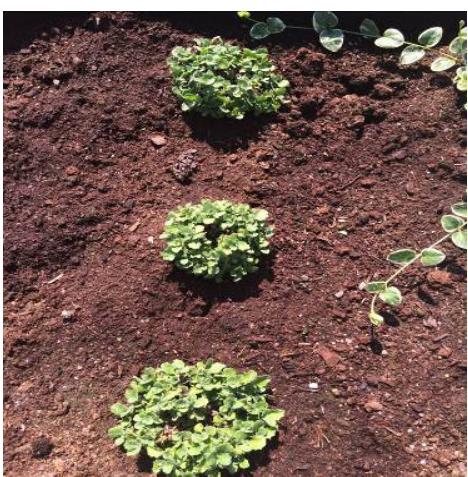

c)

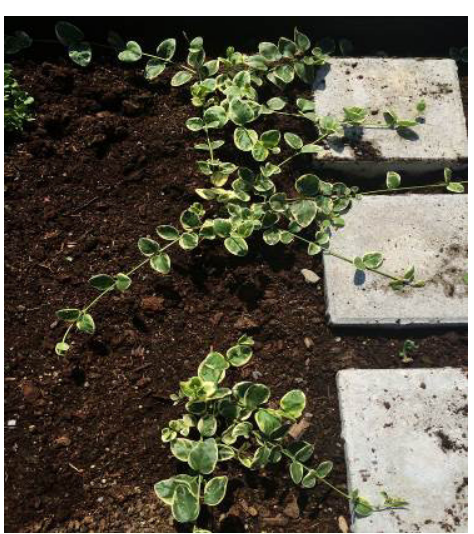

g)

Fig. 2 Arabis caucasica 'Deep Rose' (a,b,c) and Vinca major 'Variegata' plants (d,e,f) located in the roof, on different substrate types (Jult 2014): a) and d) $V_{1}$; b) and e) $-V_{2}$; c) și f) $V_{3}$. 
Rose', planted in the experimental field in the summer of 2014, we have not recorded, for any individual, any buds.

From biometric research, carried out during the vegetation period and at the beginning of June - up to the beginning of September, for the individuals belonging to the studied species we noticed that the plants have had a normal evolution, specific for each species (Fig. 2).

Under the influence of the interaction between the culture location and substrate type on the height of the Arabis caucasica 'Deep Rose' samples, we have noticed that the registered values between $3,5 \mathrm{~cm}$ and $6,0 \mathrm{~cm}$, with a variant average of $5,0 \mathrm{~cm}$. Statistically, we noticed that the difference to the variant average are negative, very significant for the roof culture system for the substrate variant comprised of forest soil $\left(V_{1}\right)$, not only regarding the diameter, but also the height of the bush.

Distinctly significant positive differences were registered in the case of the field set culture, for the variant formed from a mixture of Novobalt peat (43\%), coconut fiber (30\%), composted bark and $(23 \%)$ and alginate $(4 \%)\left(\mathrm{V}_{5}\right)$, the difference from the variant average being $2.9 \mathrm{~cm}$ for bush diameter and 1,00 in case of bush height. At the same time, significantly positive differences were registered in case of the roof culture systems, for the same substrate variant $\left(V_{2}\right)$, its value being $1.00 \mathrm{~cm}$.
For the roof cultivated plants, variant $\mathrm{V}_{3}$, comprised on blonde peat (40\%), brown peat $(30 \%)$, sand $(10 \%)$ and forest soil $(20 \%)$, the differences regarding bush diameters and height in comparison to the average are insignificant (Tab. 1).

Regarding the influence of the interaction between the culture location and substrate, the percentage in comparison to the average of the variants, concerning plant height (Tab. 1), varied between $70,00 \%$ for variant $V_{1}$ and $120,00 \%$ for variant $\mathrm{V}_{5}$.

The results regarding the influence of the interaction between the culture location and substrate on the number of shoots and their length for Arabis caucasica 'Deep Rose' plants, are presented in Table 2. The percentages towards the average varied between $76.9 \%$ and $108.91 \%$ for number of shoots /plant, namely between $67.74 \%$ and $125.81 \%$ for the shoots length, negative differences being recorded for variants $\mathrm{V}_{1}$ and $\mathrm{V}_{4}$, corresponding to cultures on forest soil substrate, both from the field and on the roof. Larger differences (very significant) were for roof variant $\left(\mathrm{V}_{1}\right)$, while field variant $\left(\mathrm{V}_{4}\right)$ had distinctly significant, namely significant differences.

By comparing the data from the scientific literature with the results from the research it is noticed that the influence of crop substances and fertilization schedule have a great importance

Tab. 1 influence of the interaction of the culture location and substrate on the growth of Arabis caucasica 'Deep Rose' plants

\begin{tabular}{|c|c|c|c|c|c|c|c|c|c|}
\hline Nr. & variant & $\begin{array}{c}\text { Bush } \\
\text { diameter } \\
\text {-cm- }\end{array}$ & $\begin{array}{l}\% \text { from } \\
\text { control } \\
\text { sample } \\
\end{array}$ & $\pm \varnothing$ & $\begin{array}{c}\text { Difference } \\
\text { significance }\end{array}$ & $\begin{array}{l}\text { Height - } \\
\text { cm- }\end{array}$ & $\begin{array}{l}\% \text { from } \\
\text { control } \\
\text { sample } \\
\end{array}$ & $\pm \varnothing$ & $\begin{array}{c}\text { Difference } \\
\text { significance }\end{array}$ \\
\hline 1 & $\mathrm{~V}_{1}$ & 10.00 & 68.49 & -4.60 & 000 & 3.50 & 70.00 & -1.50 & 000 \\
\hline 2 & $\mathrm{~V}_{2}$ & 16.70 & 114.38 & 2.10 & $*$ & 6.00 & 120.00 & 1.00 & $* *$ \\
\hline 3 & $\mathrm{~V}_{3}$ & 14.20 & 97.26 & 0.40 & - & 4.80 & 96.00 & -0.20 & - \\
\hline 4 & $\mathrm{~V}_{4}$ & 13.50 & 92.47 & 1.10 & - & 4.20 & 84.00 & 0.80 & 0 \\
\hline 5 & $\mathrm{~V}_{5}$ & 17.50 & 119.86 & 2.90 & $* *$ & 6.00 & 120.00 & 1.00 & $* *$ \\
\hline 6 & $V_{6}$ & 16.00 & 109.59 & 1.40 & - & 5.70 & 114.00 & 0.70 & $*$ \\
\hline & Average & 14.60 & 100.00 & - & $\begin{array}{l}\text { Control } \\
\text { sample }\end{array}$ & 5.00 & 100.00 & - & Control sample \\
\hline \multicolumn{6}{|c|}{$\begin{aligned} \mathrm{LSD}_{5 \%} & =1,70 \mathrm{~cm} \\
\mathrm{LSD}_{1 \%} & =2,40 \mathrm{~cm} \\
\mathrm{LSD}_{01 \%} & =3,40 \mathrm{~cm}\end{aligned}$} & \multicolumn{4}{|c|}{$\begin{aligned} \operatorname{LSD}_{5 \%} & =0,70 \mathrm{~cm} \\
\operatorname{LSD}_{1 \%} & =1,00 \mathrm{~cm} \\
\operatorname{LSD}_{01 \%} & =1,40 \mathrm{~cm}\end{aligned}$} \\
\hline
\end{tabular}


regarding the growth and decorative valences of the species used in the arragement of green roofs.

Values above variant average (positive differences) for the number and length of shoots were registered by variants $V_{2}$ and $V_{5}$, on Novobalt peat (43\%), coconut fibers (30\%), composted bark $(23 \%)$ and alginate (4\%), with higher differences (very significant and distinctly significant) in the field conditions $\left(\mathrm{V}_{5}\right)$. At the same time, in the conditions of Variant $V_{6}$, the forming of a large number of shoots/plant was favored (positive, distinctly significant differences).
For Vinca major 'Variegata', the influence of the interaction between the culture location and substrate on the bush diameter (Tab. 3) stood out through positive, very significant differences from the variant average for the field cultures, for variants $V_{5}$, substrate Novobalt peat (43\%), coconut fiber $(30 \%)$, composted bark $(23 \%)$ and alginate $(4 \%)$, and for variant $\mathrm{V}_{6}$ comprised of blonde peat (40\%), brown peat (30\%), sand (10\%) and forest soil $(20 \%)$. At the same time positive very significant differences were registered for

Tab. 2 the influence of the culture location and substrate on the number of shoots and their length for the Arabis caucasica 'Deep Rose' plant

\begin{tabular}{|c|c|c|c|c|c|c|c|c|c|}
\hline Nr. & Variant & $\begin{array}{c}\text { No. of } \\
\text { shoots/plant }\end{array}$ & $\begin{array}{l}\% \text { from } \\
\text { control } \\
\text { sample }\end{array}$ & $\pm \varnothing$ & $\begin{array}{l}\text { Difference } \\
\text { significance }\end{array}$ & $\begin{array}{c}\text { Shoots length } \\
-\mathrm{cm}-\end{array}$ & $\begin{array}{l}\% \text { from } \\
\text { control } \\
\text { sample }\end{array}$ & $\pm \varnothing$ & $\begin{array}{c}\text { Difference } \\
\text { significance }\end{array}$ \\
\hline 1 & $V_{1}$ & 23.30 & 76.90 & -7.00 & 000 & 4.20 & 67.74 & -2.00 & 000 \\
\hline 2 & $\mathrm{~V}_{2}$ & 33.00 & 108.91 & 2.70 & $* *$ & 7.30 & 117.74 & 1.10 & $*$ \\
\hline 3 & $V_{3}$ & 31.00 & 102.31 & 0.70 & - & 6.00 & 96.77 & -0.20 & - \\
\hline 4 & $\mathrm{~V}_{4}$ & 27.20 & 89.77 & -3.10 & 00 & 5.00 & 80.64 & -1.20 & 0 \\
\hline 5 & $V_{5}$ & 34.30 & 103.20 & 4.00 & $* * *$ & 7.80 & 125.81 & 1.60 & $* *$ \\
\hline 6 & $V_{6}$ & 33.00 & 108.91 & 2.70 & ** & 6.80 & 109.68 & 0.60 & - \\
\hline & Average & 30.30 & 100.00 & - & $\begin{array}{l}\text { Control } \\
\text { sample }\end{array}$ & 6.20 & 100.00 & - & $\begin{array}{l}\text { Control } \\
\text { sample }\end{array}$ \\
\hline \multicolumn{6}{|c|}{$\begin{aligned} \operatorname{LSD}_{5 \%} & =1,80 \\
\operatorname{LSD}_{1 \%} & =2,60 \\
\operatorname{LSD}_{01 \%} & =3,80\end{aligned}$} & \multicolumn{4}{|c|}{$\begin{aligned} \mathrm{LSD}_{5 \%} & =0,90 \mathrm{~cm} \\
\mathrm{LSD}_{1 \%} & =1,40 \mathrm{~cm} \\
\mathrm{LSD}_{010} & =2,00 \mathrm{~cm}\end{aligned}$} \\
\hline
\end{tabular}

Tab. 3 The influence of the interaction of the culture location and substrate on the growth of Vinca major 'Variegata'plants

\begin{tabular}{|c|c|c|c|c|c|c|c|c|c|}
\hline $\mathrm{Nr}$. & Variant & $\begin{array}{c}\text { Bush } \\
\text { diameter } \\
\text {-cm- } \\
\end{array}$ & $\begin{array}{l}\% \text { from } \\
\text { control } \\
\text { sample }\end{array}$ & $\pm \varnothing$ & $\begin{array}{l}\text { Difference } \\
\text { significance }\end{array}$ & $\begin{array}{l}\text { Shoot } \\
\text { Length } \\
\text {-cm- }\end{array}$ & $\begin{array}{l}\% \text { from } \\
\text { control } \\
\text { sample } \\
\end{array}$ & $\pm \emptyset$ & $\begin{array}{l}\text { Difference } \\
\text { significance }\end{array}$ \\
\hline 1 & $V_{1}$ & 66.30 & 75.08 & -22.00 & 000 & 36.00 & 77.92 & -10.30 & 000 \\
\hline 2 & $\mathrm{~V}_{2}$ & 90.50 & 102.49 & 2.20 & $*$ & 48.30 & 104.55 & 2.00 & - \\
\hline 3 & $\mathrm{~V}_{3}$ & 85.20 & 96.49 & -3.10 & 00 & 45.00 & 97.40 & -1.30 & - \\
\hline 4 & $\mathrm{~V}_{4}$ & 85.10 & 96.38 & -3.20 & 00 & 43.20 & 93.51 & -3.10 & - \\
\hline 5 & $\mathrm{~V}_{5}$ & 109.30 & 123.79 & 21.00 & $* * *$ & 55.50 & 120.13 & 9.20 & $* * *$ \\
\hline 6 & $\mathrm{~V}_{6}$ & 93.50 & 105.89 & 5.20 & $* *$ & 49.50 & 107.14 & 3.20 & - \\
\hline & Average & 88.30 & 100.00 & - & $\begin{array}{l}\text { Control } \\
\text { sample }\end{array}$ & 46.20 & 100.00 & - & $\begin{array}{l}\text { Control } \\
\text { sample }\end{array}$ \\
\hline \multicolumn{6}{|c|}{$\begin{aligned} \operatorname{LSD}_{5 \%} & =1,90 \mathrm{~cm} \\
\operatorname{LSD}_{1 \%} & =2,60 \mathrm{~cm} \\
\operatorname{LSD}^{2} & =3,80 \mathrm{~cm}\end{aligned}$} & \multicolumn{4}{|c|}{$\begin{aligned} \mathrm{LSD}_{5 \%} & =3,70 \mathrm{~cm} \\
\mathrm{LSD}_{1 \%} & =5,20 \mathrm{~cm} \\
\mathrm{LSD}_{011 \%} & =7,60 \mathrm{~cm}\end{aligned}$} \\
\hline
\end{tabular}


Tab. 4 The influence of the interaction of culture location and substrate on the number of shoots and number of leaves on for Vinca major 'Variegata 'plants

\begin{tabular}{|c|c|c|c|c|c|c|c|c|c|}
\hline Nr. & Variant & $\begin{array}{c}\text { No shoots/ } \\
\text { plant }\end{array}$ & $\begin{array}{l}\% \text { from } \\
\text { control } \\
\text { sample }\end{array}$ & $\pm \varnothing$ & $\begin{array}{c}\text { Difference } \\
\text { significance }\end{array}$ & $\begin{array}{c}\text { No leaves/ } \\
\text { shoot }\end{array}$ & $\begin{array}{l}\% \text { from } \\
\text { control } \\
\text { sample }\end{array}$ & $\pm \varnothing$ & $\begin{array}{c}\text { Difference } \\
\text { significance }\end{array}$ \\
\hline 1 & $\mathrm{~V}_{1}$ & 6.30 & 36.21 & -11.10 & 000 & 14.70 & 70.67 & -6.10 & 000 \\
\hline 2 & $\mathrm{~V}_{2}$ & 20.00 & 114.94 & 2.60 & $* *$ & 23.00 & 110.58 & 2.20 & $*$ \\
\hline 3 & $\mathrm{~V}_{3}$ & 18.30 & 105.17 & 0.90 & - & 22.30 & 107.21 & 1.50 & - \\
\hline 4 & $\mathrm{~V}_{4}$ & 17.30 & 99.42 & -0.10 & - & 18.70 & 89.90 & -2.10 & - \\
\hline 5 & $\mathrm{~V}_{5}$ & 22.30 & 116.67 & 4.90 & $* *$ & 24.30 & 116.83 & 3.50 & $* *$ \\
\hline \multirow[t]{3}{*}{6} & $\mathrm{~V}_{6}$ & 20.00 & 114.94 & 2.60 & $* *$ & 22.00 & 105.77 & 1.20 & - \\
\hline & Average & 17.40 & 100.00 & - & $\begin{array}{l}\text { Control } \\
\text { sample }\end{array}$ & 20.80 & 100.00 & - & $\begin{array}{l}\text { Control } \\
\text { sample }\end{array}$ \\
\hline & \multicolumn{5}{|c|}{$\begin{aligned} \operatorname{LSD}_{5 \%} & =3,30 \\
\operatorname{LSD}_{1 \%} & =4,70 \\
\operatorname{LSD}_{01 \%} & =6,90\end{aligned}$} & \multicolumn{4}{|c|}{$\begin{aligned} \operatorname{LSD}_{5 \%} & =2,20 \\
\operatorname{LSD}_{1 \%} & =3,10 \\
\operatorname{LSD}_{010 \%} & =4,50\end{aligned}$} \\
\hline
\end{tabular}

shoot length, for V5, exceeding the average by $20.13 \%$.

Very significant negative differences regarding bush diameter and shoot length were recorded in the case of the roof culture systems, for the variant of forest soil $\left(\mathrm{V}_{1}\right.$, their values being below the average by $24.92 \%$, namely $22.08 \%$.

Distinctively significant negative differences of the bush diameter were recorded in the case of the roof located cultures of variant $V_{3}$, and the field located culture, variant $V_{4}$.

For variants $V_{2}$ and $V_{3}$, located on the roof and variants $V_{4}$ and $V_{6}$, located in the field, the results regarding the length of the shoots are not statistically insured, the differences to the average being insignificant (Tab. 3).

For Vinca major 'Variegata' we have analyzed the number of shoots/plant and the number of leaves/shoot (Tab. 4).

Thus, the number of shoots/plant varied between $6.3\left(\mathrm{~V}_{1}\right)$ and $22.3\left(\mathrm{~V}_{5}\right)$. Analyzing this nature, we have registered positive differences distinctively significant in case of the plants cultivated in the field from variants $V 5$ and $V_{6}$, and for the roof cultivated plants, from variant $V_{2}$. Distinctly significant negative differences were recorded for the roof cultivated plants from V1, with about 11 shoots/plant less than the average.

The number of leaves/shoot has been between $14.7\left(\mathrm{~V}_{1}\right)$ and $24.3\left(\mathrm{~V}_{5}\right)$, the differences being statistically insured for variants V1 (distinctly significant negative differences), $\mathrm{V}_{2}$ (significant positive differences) and $\mathrm{V}_{5}$ (distinctly significant positive differences).

For the field cultivated plants from variants $\mathrm{V} 4$ and $\mathrm{V}_{5}$, and for that cultivated on the roof for variants $\mathrm{V} 3$, the registered differences were insignificant to the variant average.

\section{CONCLUSION}

1. Regardless of the used culture substrate, we have recorded the less favorable influence of the roof conditions on the Arabis caucasica 'Deep Rose' and Vinca major 'Variegata' plants.

2. Both studied species recorded poor results for the forest soil substrate, especially in the case of roof culture $\left(\mathrm{V}_{1}\right)$ where, for all analyzed characteristics the differences towards the average were negative, very significant.

3 . Type $a_{2}$, substrate made of Novobalt peat (43\%), coconut fiber (30\%), composted bark $(23 \%)$, alginite (4\%), achieved best results for the requirements of the Arabis caucasica 'Deep Rose' and Vinca major 'Variegata' plants both on the roof $\left(V_{2}\right)$, and in the field conditions $\left(V_{5}\right)$.

4. Relatively good results were also obtained for the plants cultivated on type $a_{3}$ substrate made of blonde peat (40\%), brown peat (30\%), sand (10\%) and forest soil (20\%).

Acknowledgments. The research has been carried out in the POSDRU project " The research has been carried out in the POSDRU 
project “ Doctoral and postdoctoral programs to promote excellence in research, development and innovation in priority areas - agricultural and veterinary medical based on society knowledge" coordinated by USAMV Cluj-Napoca, ID: 132765.

\section{REFERENCES}

1. Borza Al (1925). Flora of Romanian peasant gardens II.. Ed. Grăd. Bot., Cluj: 67-81.

2. Borza Al, Nyarady EI (1931). Organic Seeds Production in the Polish Seeds Companies. Ed. Ed. Grăd. Bot., Cluj 11(34): 66-88.

3. Bruce $G$ (2011). Effect of a modular extensive green roof on stormwater runoff and water quality, Ed. Elsevier, United States.

4. Cantor M (2009). General floriculture, Ed.Todesco, ClujNapoca.

5. Cantor M, Pop I (2005) Special floriculture, Editura Academic Pres, Cluj-Napoca.

6. Ceapoiu N (1968). Statistical methods in agricultural and biological experiments. Edit. AgroSilvică, București.

7. Compagnone G (2009). Modular green roof technology, Environmental Design \& Construction, ISSN 1095-8932, 10/2009, Volume 12, Issue 10: 12.

8. Cristea V, Jarda L, Holobiuc I (2013). Ex situ conservation of there endemic and/or endanggered dianthus species Notule Botanicae Horti Agrobotanici Cluj-Napoca, (41): 73-78.
9. Draghia L, Chelariu E L (2011). Floriculture. Ed. «Ion Ionescu de la Brad» Iași: 250.

10. Ehrenfeld JG. Ravit B, Elgersma K (2005). Feedback in the plant-soil system. Ed. ProQuest Central, Annual Review of Environment and Resources: 75.

11. Higgins A (2005.) Nearly Perfect Plants, Hiding Up on the Roof. Ed. The Washington Post, United States.

12. Negrea R, Draghia L, Ciobotari G (2014). The influence of some culture systems on the ornamental value of Sedum spurium 'Fuldaglut' and Sempervivum tectorum species. Lucrări Științifice, Vol. 57, Nr. 1, Seria Horticultură Ed "Ion Ionescu de la Brad": 217.

13. Pyšek P, SáLSDo J, Mandák B (2002). Catalogue of alien plants of the Czech Republic. Preslia, Praha: 102.

14. Săvulescu T (1976). Flora R. P. Romane - R. S. Romania, I-XIII. București. Ed. Acad. R. P. Romane, București.

15. Săulescu NA, Săulescu NN,(1967). Field experience. Edit. Agro-Silvică, București.

16. Șelaru E (2007). Culture of garden flowers, Ed. Ceres, București: 208.

17. Sîrbu C, Oprea A (2011). Adventive plants in the Romanian flora, Ed. Ion Ionescu de la Brad, Iași: 312.

18. Toma F (2003). Floriculture and floral art, vol. I General floriculture - Invel Multimedia, București: 140.

19. Zheng Y (2013). Optimal growing substrate $\mathrm{pH}$ for five Sedum species. Ed. AMER Soc Horticultural Science, United States. 